\title{
TANGO-Inspired Design of Anti-Amyloid Cyclic Peptides
}

\author{
Xiaomeng Lu ${ }^{\dagger}$, Claire R. Brickson $\ddagger, \S$, and Regina M. Murphy ${ }^{\ddagger}{ }^{\star}$ \\ †Biophysics Program, University of Wisconsin-Madison, Madison, Wisconsin 53706, United \\ States \\ ‡Department of Chemical and Biological Engineering, University of Wisconsin—Madison, \\ Madison, Wisconsin 53706, United States
}

\begin{abstract}
$\beta$-Amyloid peptide $(\mathrm{A} \beta)$ self-associates into oligomers and fibrils, in a process that is believed to directly lead to neuronal death in Alzheimer's disease. Compounds that bind to $\mathrm{A} \beta$, and inhibit fibrillogenesis and neurotoxicity, are of interest as an anti-Alzheimer therapeutic strategy. Peptides are particularly attractive for this purpose, because they have advantages over small molecules in their ability to disrupt protein-protein interactions, yet they are amenable to tuning of their properties through chemical means, unlike antibodies. Self-complementation and peptide library screening are two strategies that have been employed in the search for peptides that bind to $\mathrm{A} \beta$. We have taken a different approach, by designing $\mathrm{A} \beta$-binding peptides using transthyretin (TTR) as a template. Previously, we demonstrated that a cyclic peptide, with sequence derived from the known $\mathrm{A} \beta$-binding site on TTR, suppressed $\mathrm{A} \beta$ aggregation into fibrils and protected neurons against $\mathrm{A} \beta$ toxicity. Here, we searched for cyclic peptides with improved efficacy, by employing the algorithm TANGO, designed originally to identify amyloidogenic sequences in proteins. By using TANGO as a guide to predict the effect of sequence modifications on conformation and aggregation, we synthesized a significantly improved cyclic peptide. We demonstrate that the peptide, in binding to $\mathrm{A} \beta$, redirects $\mathrm{A} \beta$ toward protease-sensitive, nonfibrillar aggregates. Cyclic
\end{abstract}

\footnotetext{
"Corresponding Author: Mailing address: Department of Chemical and Biological Engineering, 1415 Engineering Drive, University of Wisconsin-Madison, Madison, WI 53706. regina.murphy@ wisc.edu. Telephone: 608-262-1587.

\$Present Address: C.R.B.: School of Medicine and Public Health, University of Wisconsin-Madison, 750 Highland Ave, Madison WI 53705.

Author Contributions

X.L. designed and synthesized the cyclic peptides CG3, CG4, CG5, CG7, and CG8, characterized their properties and interactions with $\beta$-amyloid, and wrote sections of the manuscript and prepared the figures. C.R.B. designed and synthesized the biotinylated peptide CG3b, developed the ELISA assay for measuring binding in the presence of FBS, and carried out the solubility and stability experiments. R.M.M. developed the overall strategy and supervised the work, designed experimental protocols and interpreted data, and wrote sections of the manuscript.

The authors declare the following competing financial interest(s): We have filed a patent application on the cyclic peptides.

Supporting Information

The Supporting Information is available free of charge on the ACS Publications website at DOI: 10.1021/acschemneuro.6b00150. Detailed description of data analysis using nanoparticle tracking; discussion on the relationship between the measured hydrodynamic diameter and the number of $\mathrm{Ab}$ monomers in the aggregate (PDF)

Video of $\mathrm{A} \beta$ at 0 min (MPG)

Video of $\mathrm{A} \beta$ at $120 \mathrm{~min}(\mathrm{MPG})$

Video of $\mathrm{A} \beta+\mathrm{CG} 3$ at $0 \mathrm{~min}(\mathrm{MPG})$

Video of $\mathrm{A} \beta+\mathrm{CG} 3$ at $120 \mathrm{~min}$ (MPG)

Video of $\mathrm{A} \beta+\mathrm{CG} 8$ at $0 \mathrm{~min}(\mathrm{MPG})$

Video of $\mathrm{A} \beta+\mathrm{CG} 8$ at $120 \mathrm{~min}$ (MPG)
} 
peptides designed using this strategy have attractive solubility, specificity, and stability characteristics.

\title{
Graphical Abstract
}

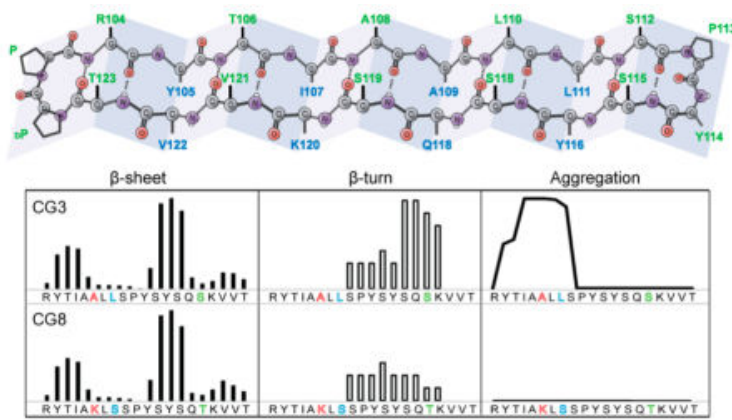

\section{Keywords}

$\beta$-Amyloid; transthyretin; cyclic peptide; Alzheimer's disease; peptide drugs; amyloid fibrils

\begin{abstract}
Alzheimer's disease (AD) accounts for $60 \%$ to $70 \%$ of all dementia cases, affecting more than 5 million people in the United States and 36 million people worldwide. Two characteristic features of $\mathrm{AD}$ are deposition of $\beta$-amyloid $(\mathrm{A} \beta)$ in extracellular senile plaques in the hippocampus and cerebral cortex, and development of intracellular neurofibrillary tangles derived from hyperphosphorylated tau. It is generally thought that $\mathrm{A} \beta$ deposition precedes tangle formation. ${ }^{1} \mathrm{~A} \beta$ is produced upon cleavage of amyloid precursor protein (APP) by $\gamma$-and $\beta$-secretases. ${ }^{2} \mathrm{~A} \beta$ monomers are intrinsically disordered, but the peptide spontaneously self-associates, progressing in both size and $\beta$-sheet content from small soluble oligomers through protofibrils to insoluble fibrillar aggregates. Although the precise mechanism of $\mathrm{AD}$ pathogenesis is unknown, the aggregation of $\mathrm{A} \beta$ is believed to be causally linked to disease onset or progression, a hypothesis known as the "amyloid cascade" hypothesis. The soluble oligomer forms of $\mathrm{A} \beta$ are targeted as the most toxic species.

Current available treatments for AD are limited to those that treat symptoms, such as acetylcholinesterase inhibitors and NMDA receptor agonists. ${ }^{3}$ These treatments are not curative and do not attack the underlying cause of the disease. Several approaches aimed at intervening in the amyloid cascade are under intensive investigation, although none have yet been successful in the clinic. ${ }^{4}$ These approaches include: inhibition of the enzymes that cleave APP and produce $\mathrm{A} \beta$, use of compounds that bind to $\mathrm{A} \beta$ and prevent its aggregation, immunization to trigger innate immune reaction against $A \beta$, dissolution of plaques for subsequent enzymatic degradation, and prevention of oxidative stress caused by $\mathrm{A} \beta$ aggregates. $^{5-7}$
\end{abstract}

Agents that can alter $\mathrm{A} \beta$ aggregation have been extensively explored. ${ }^{5,8}$ Numerous small molecule inhibitors of $\mathrm{A} \beta$ aggregation have been reported that interact with $\mathrm{A} \beta$ and alter $\mathrm{A} \beta$ aggregation. Stoichiometric or greater quantities and relatively high concentrations (5-50 
$\mu \mathrm{M})$ are typically required, and their selectivity, specificity, and mechanism of action are often unknown. ${ }^{9-12}$ Small molecules can be highly effective when their mode of action requires binding to a ligand site on a receptor or in a small cleft in an enzyme. However, protein-protein interactions typically involve a large surface area of contact, 1500-3000 $\AA^{2}$, while the typical contact area between small molecules and proteins is only $300-1000$ $\AA^{2.13,14}$ Antibody-based inhibitors occupy the other end of the molecular-size scale.

Antibodies are likely to have much better target affinity and specificity than small molecules, but they are expensive and dificult to chemically modify, and only the small antigen-binding fraction of the antibody is pharmaceutically useful. Several anti-A $\beta$ antibodies have been tested in clinical trials, but to date with at best modest results. ${ }^{15,16}$ One of the key issues in the design of anti- $\mathrm{A} \beta$ antibodies is the question as to what form of $\mathrm{A} \beta$ should be targeted. Earlier antibodies (those that have reached the clinic) targeted linear sequences, while newer ones under development target structural epitopes found in oligomers. ${ }^{15}$

Lying between small molecules and antibodies on the molecular-size continuum are peptides and peptide derivatives. Peptide drugs comprise only $2 \%$ of the worldwide pharmaceutical market currently. ${ }^{17}$ Yet they have several attractive properties compared to either small molecule drugs or large protein biologicals, including a larger interaction interface leading to better affinity and specificity than small molecules, and lower immunogenicity, lower manufacturing cost, and greater access to chemical diversity, than antibodies. ${ }^{17,18}$ In the search for peptides (or peptide-derived compounds) that inhibit $\mathrm{A} \beta$ aggregation, two general approaches have been taken. ${ }^{19}$ In one approach, peptides are designed to interact with $\mathrm{A} \beta$ through self-complementary sequences, most commonly residues 16-20 of A $\beta$ (KLVFF). Numerous variations on this approach have been published, where the sequence is modified or appending domains are attached to improve its efficacy. ${ }^{20-24}$ In a second approach, peptide libraries are screened for binding to full-length $\mathrm{A} \beta .^{25-28}$ The library-screening approach requires little or no a priori knowledge of desired sequence or structural features. The utility of this screen may depend on whether one screens for binding to the $\mathrm{A} \beta$ monomer or to the putative toxic oligomeric species.

We have explored a distinctly different approach in the search for anti-A $\beta$ peptides, by using, as templates, proteins that are known to be natural $\mathrm{A} \beta$ binders. Specifically, transthyretin (TTR), a stable homotetrameric transport protein circulating in blood and cerebrospinal fluid, has been shown to be neuroprotective against $\mathrm{A} \beta$ toxicity in vitro and in AD mouse models. ${ }^{29,30}$ Inhibition of toxicity is directly linked to TTR binding to A $\beta$; importantly TTR preferentially binds to A $\beta$ oligomers compared to fibrils, but binds only weakly to monomers. ${ }^{30-32}$ TTR, as well as a monomeric mutant (mTTR, F87M/L110M), completely inhibits $\mathrm{A} \beta$ toxicity at substoichiometric (1:100 TTR:A $\beta)$ molar ratio. We hypothesize that TTR has "solved the problem" of evolving a binding domain that is selective for toxic $\mathrm{A} \beta$ oligomers. Therefore, we speculated that a peptide mimicking the $\mathrm{A} \beta$ binding domain on TTR would have great therapeutic potential. Using several complementary techniques, we identified strand $\mathrm{G}$ and part of strand $\mathrm{H}$, at TTR's dimerdimer interface, as the $\mathrm{A} \beta$ binding domain in TTR, and delineated specific critical residues in the binding interaction. ${ }^{33}$ Of note, the putative $\mathrm{A} \beta$ binding domain on TTR is one that has been identified as amyloidogenic itself. Results consistent with and expanding on these conclusions were obtained by another group using different methods. ${ }^{32}$ A 16-mer linear 
peptide, G16, corresponding to residues 102-117 (PRRYTIAALLSPYSWS) on TTR was synthesized and showed neuroprotection against $\mathrm{A} \beta$ in vitro. ${ }^{34}$ However, G16 lacks the $\beta$ strand structure of the $\mathrm{A} \beta$ binding site on TTR. To enforce proper residue alignment and restrict conformational flexibility, a $\beta$-hairpin was inserted and an $\mathrm{N}$-to-C cyclization reaction was carried out. The cyclized 22-mer, CG3, proved to be more effective than the linear peptide at suppressing $\mathrm{A} \beta$ aggregation into fibrils, and at protecting neurons against A $\beta$ toxicity (Figure 1 ). ${ }^{35}$

Even though the protective activity of CG3 was greatly improved compared to G16, CG3 was still not as effective as native TTR. We speculated that this could be due to (a) insufficient adoption of an antiparallel $\beta$-strand structure and/or (b) a reduction in the effective concentration caused by CG3's tendency to self-associate. Thus, further improvement in our cyclic peptide strategy might be achieved by enforcing tighter conformational constraints and/or controlling self-association. To rationally improve our cyclic peptide design, we used an algorithm, TANGO, that was developed to predict amyloidogenic sequences in proteins. ${ }^{36}$ Briefly, TANGO uses a statistical mechanical approach to predict aggregation-prone regions in proteins, by looking at physicochemical features such as $\beta$-sheet propensity and hydrophobicity. In this work, we used TANGO to guide us in selecting specific mutations that would retain or stabilize the antiparallel twostranded $\beta$-sheet of the A $\beta$-binding domain of TTR, while minimizing self-association. Our work demonstrates that through rational design guided by an amyloid prediction algorithm, we successfully improved the performance of cyclic peptides that act as anti-amyloid agents.

\section{RESULTS AND DISCUSSION}

\section{Selectivity, Solubility, and Stability of CG3}

Previously we demonstrated that the cyclic peptide CG3 bound A $\beta$ in phosphate-buffered saline (PBS), and inhibited $\mathrm{A} \beta$ toxicity against primary hippocampal neuronal-enriched cultures. ${ }^{35}$ In this work, we tested whether CG3 retained $A \beta$ binding in the presence of serum proteins. $\mathrm{A} \beta$ (preaggregated for 1 day) bound nonspecifically to NeutrAvidin-coated plates, with a linear increase in binding with increased $\mathrm{A} \beta$ concentration (Figure 2). Nonspecific binding was completely eliminated in $10 \%$ or $30 \%$ fetal bovine serum (FBS). Biotinylated CG3 (CG3b) was immobilized on NeutrAvidin-coated plates, and binding of $\mathrm{A} \beta$ in PBS in $10 \% \mathrm{FBS}$ or in $30 \%$ FBS to immobilized CG3b was measured. Binding increased as $\mathrm{A} \beta$ concentration increased, leveling off at higher $\mathrm{A} \beta$ concentration as $\mathrm{CG} 3 \mathrm{~b}$ became saturated. FBS diminished $\mathrm{A} \beta$ binding only slightly, with the decrease attributable to the elimination of nonspecific binding. Since the serum protein concentration at these conditions is $3-13 \mathrm{mg} / \mathrm{mL}$, these results demonstrate strong selective binding of $\mathrm{A} \beta$ to CG3 even at $>1000$-fold excess nonspecific protein. From the binding curve, one can estimate an apparent $K_{\mathrm{d}}$ of $\sim 200 \mathrm{nM}$. This value must be treated cautiously, though, because the stoichiometry of binding and the degree of aggregation of $\mathrm{A} \beta$ are not known.

We next tested the solubility of CG3 by dissolving lyophilized peptide in a small amount of PBS and incubating for $24 \mathrm{~h}$ with gentle mixing. We achieved $265 \mu \mathrm{M}$ without any increase in turbidity (as measured by absorbance at $620 \mathrm{~nm}$ ), indicating the solubility in PBS is greater than $0.65 \mathrm{mg} / \mathrm{mL}$. In water, we observed solubilities exceeding $600 \mu \mathrm{M}(1.5 \mathrm{mg} / \mathrm{mL})$. 
To measure stability in physiological fluids, CG3 peptide was diluted in simulated intestinal fluid (SIF, pH 6.8) or simulated gastric fluid (SGF, pH 1.2). Immediately after preparation or after $4 \mathrm{~h}$ incubation, samples were neutralized with $\mathrm{NaOH}$ and then analyzed by mass spectrometry. The main peak in the mass spectra corresponded to the correct molecular weight of CG3 and there was no change in spectra between 0 and $4 \mathrm{~h}$ incubation (data not shown). Taken together, these results indicate that the cyclic peptide CG3 has favorable selectivity, solubility, and stability characteristics.

\section{Design and Synthesis of Cyclic Peptides}

Although the cyclic peptide CG3 was more effective than the linear peptide G16, it was not as effective as native TTR. One possible explanation for the lower efficacy of CG3 compared to TTR is insufficient conformational mimicry; in other words, the cyclic peptide might not adopt the full antiparallel $\beta$-strand structure of the native protein. A second possible explanation arises from observation, based on cross-linking and light scattering studies, that CG3 tends to form small soluble clusters. ${ }^{35}$ Self-association reduces the peptide's effective concentration and might reduce its activity. Therefore, we set out to design improved cyclic peptides by either enhancing conformational mimicry or reducing the propensity for self-association. Several constraints were placed on the design. First, we kept all the amino acids on the putative $\mathrm{A} \beta$ binding surface (Figure $3 \mathrm{a}$ ), presuming that these residues are needed to maintain $\mathrm{A} \beta$ binding capability. Second, $\mathrm{Q} 118$ is needed for the cyclization chemistry and so was retained. Also retained were K120 and Y105, because cross-strand lysine-tyrosine interactions are believed to stabilize $\beta$-hairpins. ${ }^{37}$ Finally, we kept V122 and I107, both of which have high $\beta$-sheet propensity, P113 as a turn-inducing element, and the ${ }^{\mathrm{D}}$ Pro-Pro $\beta$-turn template.

Given these constraints, we searched for sequence changes that would stabilize the antiparallel $\beta$-sheet conformation, by mutating to amino acids with higher $\beta$-sheet propensity or by introducing stabilizing interactions between the two $\beta$-strands. We also set out to reduce the propensity to self-associate. In order to carry out our search systematically, we turned to amyloid predictors-algorithms that are used to search for aggregation-prone "hot spots". We evaluated sequence changes by using the TANGO algorithm to help us design anti-amyloid molecules with a greater conformational match to the TTR template but lower propensity to self-associate. Two regions of opportunity for improvement were identified (Figure $3 \mathrm{~b}-\mathrm{d}$ ). First, there is an undesirably high $\beta$-turn score in the cyclization region SQSK (117-120 in TTR), a region that should lie in the center of one of the $\beta$ strands. Human TTR has a threonine at residue 119 but in designing CG3 we changed it to serine to improve cyclization efficiency. Changing S119 back to the native T119 substantially reduces the $\beta$-turn score at this position. This change (S119T) is denoted CG4. Second, YTIAALL (105-110 in TTR) has a high aggregation score, indicating a propensity for self-association. To lower the aggregation score, alanine was changed to lysine (A109K, denoted CG5). This change has the additional effect of introducing stabilizing interactions between lysine on one $\beta$-strand and tyrosine (Y116) on the other. ${ }^{37}$ This A109K modification causes the TANGO aggregation score to drop to zero, with little or no change in $\beta$-turn or $\beta$-sheet propensity. We also used TANGO to evaluate changing L111 to a polar/ charged residue, with the goal of reducing hydrophobicity without changing conformation. 
Initially we chose L111T (denoted CG6) because of its reduced aggregation score and enhanced $\beta$-sheet score. However, for unknown reasons and despite repeated efforts, CG6 was not stable and spontaneously degraded to smaller fragments after purification. We therefore designed L111S (CG7), based on predictions of a significant decrease in aggregation, but at the cost of a slightly lower $\beta$-sheet score compared to CG3. Finally, these three changes were combined (S119T/A109K/L111S, denoted CG8). In CG8, the problematic $\beta$-turn is reduced and the aggregation score is decreased to zero, while the $\beta$ sheet score remains relatively high.

\section{Characterization of Peptides}

Each designed peptide was synthesized and purified, and its identity and purity were confirmed by mass spectrometry. The properties of each peptide are summarized in Table 1 . The effect of amino acid change on secondary structure was confirmed by circular dichroism (CD). The decrease in the absolute molar ellipticity (less negative) at $\sim 197 \mathrm{~nm}$ was interpreted as a decrease in disorder, based on spectra obtained from model peptides. . $^{38,39}$ From these data we assess that the random coil content of each peptide increases in the order CG4 < CG5 CG3 CG8 < CG7. The hydrophilicity of the peptides was measured by determining the elution time on reverse-phase high performance liquid chromatography (RPHPLC), with the more hydrophilic peptides requiring shorter elution times. The hydrophilicity of the peptides decreases in the order CG7 CG8 > CG5 > CG4 CG3. CG4 has the same hydrophobicity as CG3 but more $\beta$-content, while CG8 is more hydrophilic but similar in $\beta$-content as CG3. In general, these changes in secondary structure and hydrophilicity are consistent with TANGO predictions.

To assess peptide stability against proteolysis, CG peptides were incubated with proteinase $\mathrm{K}$ for $1 \mathrm{~h}$, then the solution was evaluated by mass spectrometry. The ratio of cyclic to linear peptides was calculated from the heights of the respective peaks as a measure of protease stability. As shown in Table 1, CG8 is the most stable, followed by CG5, CG7, CG4, and then CG3.

\section{Interaction of Cyclic Peptides with $\mathbf{A} \beta$}

We tested whether the $\mathrm{CG}$ peptides retained the ability to bind to $\mathrm{A} \beta$ oligomers using a previously described photoinduced cross-linking (PICUP) protocol. ${ }^{34}$ Preaggregated A $\beta$ (30 $\mu \mathrm{M}$ incubated for $24 \mathrm{~h}$ at $37^{\circ} \mathrm{C}$ ) was mixed with peptides at 10:1 molar excess of $\mathrm{A} \beta$ and incubated for $1 \mathrm{~h}$. The mixture was cross-linked, separated on a tricine gel, and imaged using the anti-A $\beta$ antibody $4 \mathrm{G} 8$ (Figure $4 \mathrm{a}$ ). For $\mathrm{A} \beta$ alone we observed a ladder of monomer, dimer, trimer, tetramer, and pentamer, consistent with previous reports. ${ }^{34,35}$ When $\mathrm{A} \beta$ was mixed with the CG peptides, a smear of higher-molecular-weight oligomers (pentamer or larger) was observed. Since only $\mathrm{A} \beta$ is detected in this assay, this is taken as evidence of formation of $\mathrm{A} \beta$-CG complexes. Among these five peptides, CG8 showed the most interaction with $\mathrm{A} \beta$, based on the denser high-molecular-weight band and reduced densities for the $\mathrm{A} \beta$ monomer/dimer/trimer bands. We next examined the dependence of $\mathrm{A} \beta$ binding on the concentration of CG3 and CG8 using the same cross-linking assay. Briefly, CG3 and CG8 at a final concentration varying from 0.7 to $5.6 \mu \mathrm{M}$ was incubated with preaggregated $\mathrm{A} \beta$ (24 $\mu \mathrm{M}$ final concentration), cross-linked, and separated by gel electrophoresis (Figure 
$4 b$ ). Densities of high-molecular-weight bands were quantified using ImageJ (Figure 4c). At $5.6 \mu \mathrm{M}$, the oligomer band of CG8+A $\beta$ was about $30 \%$ denser than that of CG3+A $\beta$. The density of the broad oligomer band decreased as cyclic peptide concentration decreased, as expected. At $0.7 \mu \mathrm{M}$, there was at most a barely perceptible oligomer band with CG3, while the oligomer band density for CG8 at $0.7 \mu \mathrm{M}$ was about the same as that of CG3 at $1.4 \mu \mathrm{M}$. Taken together, these results suggest at least a 2-fold higher affinity of CG8 than CG3 for $\mathrm{A} \beta$.

We used ThT fluorescence intensity as a measure of the effect of CG peptides on $\mathrm{A} \beta$ fibril formation. ThT is widely used to detect amyloid fibrils. The dye binds to cross- $\beta$ fibrillar aggregates, resulting in a significant increase in fluorescence intensity that is presumed proportional to the mass of fibrillar aggregates. ${ }^{40} \mathrm{CG}$ peptides alone were ThT-negative (data not shown). A $\beta$ samples ( $28 \mu \mathrm{M})$ alone or with CG peptides prepared at 10 -fold, 20fold, and 100 -fold $\mathrm{A} \beta$ molar excess were incubated at $37^{\circ} \mathrm{C}$ for up to 2 days. Solutions were sampled at three time points up to $48 \mathrm{~h}$. With $\mathrm{A} \beta$ alone, ThT signal intensity was close to background after $4 \mathrm{~h}$ but increased significantly at $24 \mathrm{~h}$, as expected, and remained high at $48 \mathrm{~h}$. At 10:1 A $\beta /$ peptide molar ratio, all peptides were able to fully inhibit ThT fluorescence (Figure 5a). At 20:1 A $\beta$ /peptide ratio, CG3, CG4, CG5, and CG7 partially inhibited A $\beta$ fibril formation but CG8 still completely suppressed ThT fluorescence (Figure 5b). At 100:1 $\mathrm{A} \beta /$ peptide ratio, ThT fluorescence intensity of all samples with peptides was slightly lower than $\mathrm{A} \beta$ alone, but still above background (Figure $5 \mathrm{c}$ ). Although no longer fully inhibiting A $\beta$ fibril formation, CG8 was better than CG3 at reducing ThT fluorescence even at this very low peptide concentration $(p<0.002)$.

\section{Detailed Comparison of CG3 and CG8}

Taken together, these results show that the triple mutant CG8 is demonstrably better than CG3 in terms of $\mathrm{A} \beta$ binding and inhibition of ThT fluorescence. Given these results, we chose CG3 and CG8 for more detailed characterization of their effect on $\mathrm{A} \beta$ aggregation.

Amyloid fibrils are known to be protease-resistant, ${ }^{41}$ and so we developed a proteolytic fragmentation assay as another means to confirm that $\mathrm{A} \beta$ fibril formation is inhibited by our cyclic peptides. A $\beta(20 \mu \mathrm{M})$ alone or mixed with CG3 or CG8 $(1.4 \mu \mathrm{M})$ was incubated for $24 \mathrm{~h}$. Proteinase $\mathrm{K}$ was added, aliquots were removed at several time points, and the amount of nondegraded $\mathrm{A} \beta$ was assessed by anti- $\mathrm{A} \beta$ antibody detection. Any fibrils formed during the $24 \mathrm{~h}$ incubation period prior to proteinase $\mathrm{K}$ addition should delay proteolytic degradation. Consistent with formation of protease-resistant fibrils, $\mathrm{A} \beta$ degraded slowly, with a substantial fraction of $A \beta$ remaining after $2 \mathrm{~h}$ treatment with protease (Figure $6 \mathrm{a}$ ). In contrast, when $\mathrm{A} \beta$ was preincubated with $\mathrm{CG} 3$, degradation was detected within 5 min of protease addition, and was complete by $50 \mathrm{~min}$. When mixed with CG8 (or mTTR), A $\beta$ proteolysis was further accelerated, with complete degradation within 20-30 min. These results are consistent with the ThT fluorescence assay, indicating that both CG3 and CG8 inhibit $\mathrm{A} \beta$ fibril formation, but CG8 is more effective than CG3.

We next evaluated how CG3 and CG8 influenced $\mathrm{A} \beta$ aggregation kinetics and aggregate morphology. Several methods were used: dynamic light scattering (DLS) to measure the hydrodynamic size, nanoparticle tracking analysis (NTA) to obtain a size distribution and 
number concentration of soluble aggregates, and transmission electron microscopy (TEM) to visualize the morphology, size, and relative number of aggregates. $\mathrm{A} \beta(28 \mu \mathrm{M})$ was prepared alone or with CG3 or CG8 peptides, at a 20:1 molar excess of $\mathrm{A} \beta$, and then samples were analyzed by DLS immediately after preparation. CG3 and CG8 alone were too dilute (at 1.4 $\mu \mathrm{M})$ to contribute to any scattered intensity above background (data not shown). $\mathrm{A} \beta$ alone aggregated slowly but consistently over the $2 \mathrm{~h}$ measurement period, reaching a mean hydrodynamic diameter of $400 \mathrm{~nm}$ after $2 \mathrm{~h}$. With addition of either CG3 or CG8, the size and growth rate of $\mathrm{A} \beta$ aggregates increased, with the effect of CG8 more pronounced than that of CG3 (Figure 7a).

To further analyze aggregates in solution, we turned to nanoparticle tracking analysis (NTA), a particle-by-particle counting method. In NTA, scattered light from each particle in solution is imaged and tracked in a video camera. From analysis of the particle trajectory, a diffusion coefficient (and hence hydrodynamic diameter) for each particle can be measured. The particle data can then be combined to produce a size distribution or a number-averaged size. In addition, particle number concentration can be determined. A drawback is that, for proteins, only particles larger than $\sim 30 \mathrm{~nm}$ can be detected. Samples were prepared as for the DLS experiments ( $28 \mu \mathrm{M} \mathrm{A} \beta, 1.4 \mu \mathrm{M}$ CG3 or CG8). There were no detectable particles above background from CG3 or CG8 peptides in the absence of $A \beta$ (data not shown). A $\beta$ alone started from a few small aggregates with a mean hydrodynamic diameter of $\sim 80 \mathrm{~nm}$, consistent with the initial size measurement from DLS. Over the course of $2 \mathrm{~h}, \mathrm{~A} \beta$ aggregated steadily, with both the average hydrodynamic size and number concentration increasing (Figures 7b,c and 8a,b). At $2 \mathrm{~h}$, the mean hydrodynamic size from DLS was larger than that from NTA, because NTA yields a number-averaged diameter whereas DLS yields an intensity-averaged diameter, indicative of a broad particle size distribution.

When $\mathrm{A} \beta$ was incubated with CG3, about 2-fold more particles with a larger mean hydrodynamic diameter $(120 \mathrm{~nm})$ were detected shortly after mixing, compared to $\mathrm{A} \beta$ alone (Figures $7 \mathrm{~b}, \mathrm{c}$ and $8 \mathrm{c}, \mathrm{d}$ ). The mean hydrodynamic diameter increased to $\sim 400 \mathrm{~nm}$ after $2 \mathrm{~h}$; a trend that is consistent with DLS data. The particle number concentration increased for the first 40 min but stayed stable after that. The effect of CG8 on $\mathrm{A} \beta$ aggregation was more pronounced. The initial particle number concentration was 7-fold greater than that for $\mathrm{A} \beta$ alone, and the mean hydrodynamic diameter was larger (Figure $7 \mathrm{~b}, \mathrm{c}$ and $8 \mathrm{e}, \mathrm{f}$ ). In contrast to $\mathrm{A} \beta$ alone or with $\mathrm{CG} 3$, the number concentration of aggregates in the $\mathrm{A} \beta+\mathrm{CG} 8$ mixture decreased over time, while the size of aggregates increased rapidly, reaching $\sim 550 \mathrm{~nm}$ at 100 $\min$. After $2 \mathrm{~h}$, very large clusters of aggregates appeared, which scattered too strongly to conduct a meaningful analysis.

Taken together, these results indicate that CG3 and particularly CG8 cause rapid coalescence of small $\mathrm{A} \beta$ aggregates, but suppress the appearance of new aggregates over time. Closer direct observance of NTA videos provides further clues (Supporting Information Figure 1). Briefly, most of the aggregates formed by A $\beta$ alone were elongated in shape after $2 \mathrm{~h}$ incubation (Figure $8 \mathrm{~b}$ inset, Supporting Information Figure 1). The elongated aggregates are likely prefibrillar aggregates (protofibrils) because at these conditions the samples are ThTnegative. For $\mathrm{A} \beta$ with $\mathrm{CG} 3$, elongated aggregates were also detected, but were fewer in number, and there also appeared some larger clusters of aggregates. For A $\beta$ with CG8, in 
contrast, after $2 \mathrm{~h}$ no elongated aggregates were observed; rather, aggregates appeared to be large clusters. These data suggest that CG8 is able to redirect $\mathrm{A} \beta$ aggregates toward a nonfibrillar morphology. From NTA, one also obtains a particle-by-particle measure of the scattered intensity. It can be shown that long rodlike particles have a lower scattered intensity than globular particles of the same hydrodynamic diameter. ${ }^{42}$ We plotted the scattered intensity versus particle size for each particle, at a time point where the average size was $\sim 130 \mathrm{~nm}$ (Supporting Information videos). On average, aggregates of A $\beta+\mathrm{CG} 8$ scattered light more strongly than aggregates of the same size for $\mathrm{A} \beta$ alone. Our results are consistent with the hypothesis that $\mathrm{A} \beta+\mathrm{CG} 8$ aggregates are morphologically distinct from those of $\mathrm{A} \beta$ or $\mathrm{A} \beta+\mathrm{CG} 3$ aggregates, with a more globular and less extended structure. This work also illustrates the potential power of NTA as a label-free, noninvasive, and nondestructive means of characterizing protein aggregates with respect to not only aggregate size and number concentration, but also aggregate morphology.

Finally, we examined samples of $A \beta$ alone or with CG3 or CG8 by TEM (Figure 9). After $24 \mathrm{~h}$ incubation, $\mathrm{A} \beta$ alone aggregated into well-defined fibrils (Figure 9a,b). With CG3, there were still a large number of fibrils, but many appeared to be shorter (Figure 9c,d). In the $\mathrm{CG} 8+\mathrm{A} \beta$ sample, strikingly few fibrils were observed; rather, there were a few clustered amorphous aggregates (Figure 9e,f). These images are consistent with the data from the scattering experiments. Specifically, these data show that CG8 prevents the development of $\mathrm{A} \beta$ fibrils and redirects any aggregates into large nonfibrillar clusters. Because these clusters are nonfibrillar, they are ThT negative and are rapidly degraded by proteases.

\section{Summary}

In our prior work, we showed that CG3, a cyclic peptide designed with TTR as a template, binds to $\mathrm{A} \beta$ and inhibits $\mathrm{A} \beta$ toxicity in cell culture. ${ }^{35}$ In this study, we first ascertained that CG3 has attractive properties as a peptide drug lead compound: it has excellent solubility in water and buffer, retains high binding to $\mathrm{A} \beta$ in the presence of serum proteins, and is relatively stable in simulated gastric and intestinal fluids. Although much improved compared to a linear peptide, CG3 was less effective than TTR. To search for improved peptides, we turned to an amyloid predictor tool to evaluate modifications that would remove an unwanted $\beta$-turn propensity, enhance $\beta$-sheet stability, and increase hydrophilicity. Although others have used aggregation-predicting algorithms to redesign peptides for reduced aggregation, ${ }^{43}$ to our knowledge, this is the first time that an amyloid algorithm has been used to design an anti-amyloid peptide.

Based on this analysis, we designed, synthesized, and characterized cyclic peptides that differed from CG3 by one or three residues. One of the key changes, we believe, is the replacement of S119 in CG3 with threonine, as in the native TTR. In our initial synthesis we were concerned that the branched threonine would interfere with effective cyclization. However, serine in that position favors a $\beta$-turn in a location where a $\beta$-strand is wanted. Overall, $\beta$-sheets are depleted in serine but enriched in threonine, ${ }^{44}$ suggesting a role of a $\beta$ branch side-chain geometry in stabilizing $\beta$-sheets. CG4 (S119T) had greater $\beta$-sheet content and similar hydrophilicity to CG3, while CG7 (L111S) was more hydrophilic but somewhat reduced in $\beta$-sheet. In CG8 (S119T/A109K/L111S), we found a design that 
balanced retention of the $\beta$-sheet signature of CG3 with a reduction in aggregation propensity. These combined changes led to an improved peptide that inhibited $\mathrm{A} \beta$ fibrillogenesis more efficiently than CG3.

Through the use of multiple complementary techniques, we demonstrated that CG8 facilitates clustering of $\mathrm{A} \beta$ into large weakly associating aggregates and traps $\mathrm{A} \beta$ in an early nonfibrillar aggregation stage. This may prove to be a highly effective mechanism of action for two reasons. First, only substoichiometric quantities of cyclic peptide are needed. Second, monomeric $\mathrm{A} \beta$ is readily degraded by proteases, and early oligomers are also susceptible, but the farther $\mathrm{A} \beta$ aggregation state has proceeded toward fibrillar aggregates, the harder it is for proteases to digest it. ${ }^{41,45}$ By trapping $A \beta$ as nonfibrillar aggregates, CG8 may accelerate natural mechanisms of clearance of $\mathrm{A} \beta$.

\section{METHODS}

\section{Peptide Synthesis and Purification}

All materials were purchased from Fisher Scientific (Pittsburgh, PA) except where indicated. Peptides were synthesized using standard Fmoc solid-phase method on the Symphony peptide synthesizer (Protein Technologies, In., Tucson, AZ). The resin used was Fmoc-PALPEG-PS from Applied Biosystems (Foster City, CA). Extended and double couplings were used to improve yield.

Cyclic peptides (CG3, CG4, CG5, CG7, and CG8) were synthesized using an orthogonally protected glutamic acid derivative Fmoc-Glu-ODmab (Novabiochem, La Jolla, CA) coupled to resin through the unprotected side chain. Assembly of the peptide backbone was done using standard Fmoc solid-phase method and the last Fmoc group was removed. The onbead peptides were treated with $2 \%$ hydrazine monohydrate in dimethylformamide (DMF) to remove Dmab protecting group and reacted with 10\% diisopropylethylamine (DIPEA) in DMF. For peptide cyclization, an equimolar amount of benzotriazol-1-yloxytripyrrolidinophosphonium hexafluorophosphate (PyBOP) was added to the resin bound peptides, and incubated for 18h. In CG8 synthesis, to enhance the coupling efficiency between the C-terminal Glu and the branched N-terminal Thr, the cyclization reaction with PyBOP incubation was repeated. The double extended coupling increased the yield significantly. In the first round cyclization, the ratio of cyclic to linear was $\sim 2: 5$ as measured by mass spectrometry, and after the second round of cyclization, the main product was cyclized peptides. Peptides were cleaved from the resin and purified by RP- HPLC on a Vydac C18 column. Peptides were eluted from the column with a gradient of acetonitrile and water with $0.1 \%$ TFA at $2 \mathrm{~mL} / \mathrm{min}$. Confirmation of identities and purity were obtained by matrix-assisted laser desorption/ionization time-of-flight (MALDI-ToF) mass spectrometry. Measured molecular weights are 2423.28 (CG3, 2423.77 theoretical), 2437.36 (CG4, 2437.84 theoretical), 2480.39 (CG5, 2480.93 theoretical), 2397.22 (CG7, 2397.76 theoretical), and 2468.37 (CG8, 2468.88 theoretical).

Biotinylated CG3 (CG3b) was synthesized using standard solid phase methods, with FmocGlu(biotinyl-PEG)-OH (Novabiochem, La Jolla, CA) replacing Val121. The biotin tag provides a handle for immobilization via binding to streptavidin or derivatives, and the PEG 
linker between biotin and peptide was used to increase the flexibility and hydrophilicity and decrease any unwanted surface effects during immobilization. Fmoc-Glu(biotinyl-PEG)-OH was dissolved in 1:1 dimethyl sulfoxide (DMSO)/ $\mathrm{N}$-methyl-2-pyrrolidone (NMP) instead of dimethylformamide (DMF). Peptides were purified by RP-HPLC same as above. Purified peptide was collected and lyophilized, and identity was confirmed by MALDI-ToF mass spectrometry.

Purified peptides were dissolved in $0.22 \mu \mathrm{m}$ filtered water, and the concentrations were determined by absorbance at $205 \mathrm{~nm}$ with molar absorptivity calculated for each peptides based on their sequence. ${ }^{46}$ Peptides were then diluted to $0.6 \mathrm{mM}$, aliquoted, snap-frozen, and stored at $-80{ }^{\circ} \mathrm{C}$.

\section{Expression and Purification of $\mathrm{mTTR}$}

Recombinant human transthyretin mutant F87M/L110 M (mTTR) was produced and purified as previously described in detail. ${ }^{31}$

\section{A $\beta$ Sample Preparation}

A $\beta(1-40)$ was purchased from Anaspec, Inc. (Fremont, CA) as lyophilized powder and used without further purification for enzyme-linked immunoassay. A $\beta(1-40)$ purchased from American Peptide (Sunnyvale, CA) was used for all other experiments. For CD, DLS, ThT fluorescence assay, TEM, and NTA measurement, $\mathrm{A} \beta$ was dissolved in $50 \%$ acetonitrile, relyophilized, and reconstituted in urea/glycine buffer at $12 \mathrm{mg} / \mathrm{mL}$ as described. ${ }^{30} \mathrm{~A} \beta$ stock was then aliquoted, snap-frozen, and stored at $-80^{\circ} \mathrm{C}$. Before use, $\mathrm{A} \beta$ was thawed; $0.5 \mu \mathrm{L} 1$ $\mathrm{M} \mathrm{NaOH}$ was added to each $4 \mu \mathrm{L}$ aliquot, and the sample was allowed to sit for $20 \mathrm{~min}$ to fully dissolve $\mathrm{A} \beta$ before being diluted into phosphate-buffered saline with azide (PBSA, 10 $\mathrm{mM} \mathrm{Na} 2 \mathrm{HPO}_{4} / \mathrm{NaH}_{2} \mathrm{PO}_{4}, 150 \mathrm{mM} \mathrm{NaCl}$ and $0.02 \% \mathrm{NaN}_{3}, \mathrm{pH}$ 7.4). For PICUP and proteolytic fragmentation analysis, lyophilized $\mathrm{A} \beta$ was dissolved in prechilled hexafluoroisopropanol (HFIP, Acros Organics, Geel, Belgium), aliquoted, dried and stored at $-20{ }^{\circ} \mathrm{C}$ as previously described. ${ }^{34} \mathrm{HFIP}$-treated $\mathrm{A} \beta$ was reconstituted by dissolving in 50 $\mathrm{mM} \mathrm{NaOH}$ to $1 \mathrm{mg} / \mathrm{mL}$, sonicating for $5 \mathrm{~min}$ and diluting into PBSA to desired concentration ( 25 or $30 \mu \mathrm{M})$. All buffers were filtered through a $0.02 \mu \mathrm{m}$ filter before use.

\section{Enzyme-Linked Immunoassay (ELISA)}

NeutrAvidin coated plates (Pierce, Rockford, IL) were preblocked with SuperBlock blocking buffer and then coated with $5 \mu \mathrm{g} / \mathrm{mL}$ of CG3b (100 $\mu \mathrm{L} /$ well) for $1 \mathrm{~h}$. The plate was washed three times with wash buffer (PBST, $10 \mathrm{mM} \mathrm{Na}_{2} \mathrm{HPO}_{4} / \mathrm{NaH}_{2} \mathrm{PO}_{4}, 150 \mathrm{mM} \mathrm{NaCl}$ with $0.05 \%$ Tween 20). For a negative control, CG3b was not coated but wells were incubated with blocking buffer. Five replicate wells were prepared at each condition. A $\beta$ was preaggregated at $28 \mu \mathrm{M}$ in PBSA for $24 \mathrm{~h}$ and then diluted to $1,3,5 \mu \mathrm{g} / \mathrm{mL}$ in PBS with or without $10(\mathrm{v} / \mathrm{v}) \%$ or $30(\mathrm{v} / \mathrm{v}) \%$ fetal bovine serum (FBS, 30-45 mg/mL protein, charcoal stripped, Thermo Fisher Scientific, Waltham, MA) and then immediately added to CG3bcoated or negative control wells (50 $\mu \mathrm{L} /$ well). For background, PBS was added instead. The plate was incubated at $37{ }^{\circ} \mathrm{C}$ for $1 \mathrm{~h}$. After washing the plate, anti-A $\beta$ antibody $6 \mathrm{E} 10$ (Covance, Princeton, NJ) was diluted (1:3000) in PBST, added to each well (100 $\mu \mathrm{L} /$ well), and incubated at room temperature for $1 \mathrm{~h}$ with gently shaking. After washing, Superclonal 
anti-mouse HRP antibody (Pierce) was diluted (1:3000) in PBST, added to each well (100 $\mu \mathrm{L} /$ well), and incubated for $1 \mathrm{~h}$ at room temperature with gentle shaking. The plate was washed three times with wash buffer, and then $100 \mathrm{~mL}$ of 3,3',5,5' -tetramethylbenzidine substrate solution (TMB, Pierce) was added into each well. The plate was incubated at room temperature until the center of the well turned blue. Development was stopped by adding $100 \mu \mathrm{L}$ of $2 \mathrm{M}$ sulfuric acid to each well. Absorbance was measured at $450 \mathrm{~nm}$ with an EL800 Universal Microplate Reader (Biotek Instruments Inc., Winooski, VT). A $\beta$ binding was calculated subtracting the absorbance of the negative control from the sample absorbance. Data are reported as the mean \pm SD of five replicate wells.

\section{Stability and Solubility of Cyclic Peptides}

To determine solubility, a small volume of PBS was added to lyophilized CG3 and gently mixed for $24 \mathrm{~h}$ to reach equilibrium. The dissolved concentration was measured using Nanodrop (Thermo Fisher Scientific), and the turbidity was measured by absorbance at 620 $\mathrm{nm}$. To test for stability in simulated gastric or intestinal fluid (SGF or SIF, respectively, Sigma-Aldrich, St. Louis, MO), CG3 was diluted into SGF or SIF to a peptide concentration of $0.1 \mathrm{mg} / \mathrm{mL}$. Immediately after dilution, or after $4 \mathrm{~h}$ incubation at $37^{\circ} \mathrm{C}$, an equal volume of cold $\mathrm{ddH}_{2} \mathrm{O}$ was added to sample solutions followed by sufficient $1 \mathrm{M} \mathrm{NaOH}$ to neutralize $\mathrm{pH}$. Samples were then desalted by solid-phase extraction (SPE) and analyzed by MALDI-ToF mass spectrometry. To determine the stability of the peptides against proteinase $\mathrm{K}$, a mixture of five cyclic peptides was prepared in PBS with each peptide concentration at $30 \mu \mathrm{M}$. Peptide mixture alone or with proteinase K (Promega, Madison, WI. final concentration of $0.5 \mu \mathrm{g} / \mathrm{mL}$ ) was incubated for $1 \mathrm{~h}$ at $37^{\circ} \mathrm{C}$. Samples were then acidified by formic acid, desalted by SPE, and analyzed by MALDI-ToF mass spectrometry.

\section{Circular Dichroism (CD)}

Cyclic peptide stock solutions were diluted into phosphate buffer with sodium fluoride (10 $\mathrm{mM} \mathrm{Na} 2 \mathrm{HPO}_{4} / \mathrm{NaH}_{2} \mathrm{PO}_{4}$, and $140 \mathrm{mM} \mathrm{NaF}, \mathrm{pH}$ 7.4) to a peptide concentration of $45 \mu \mathrm{M}$. Freshly prepared sample were filtered through a $0.45 \mu \mathrm{m}$ filter directly into a $1 \mathrm{~mm}$ cell. CD spectra were collected on an Aviv 202SF CD spectrophotometer from Aviv Biomedical (Lakewood, NJ) at $25^{\circ} \mathrm{C}$. Three scans were taken and averaged. Solvent spectra were collected and subtracted.

\section{Photoinduced Cross-Linking (PICUP) of $\mathrm{A} \beta$ and Peptides}

$\mathrm{A} \beta$ was diluted into PBSA at $30 \mu \mathrm{M}$ and incubated for $24 \mathrm{~h}$ at $37^{\circ} \mathrm{C}$. A $\beta$ was mixed with peptides to a final concentration of $24 \mu \mathrm{M} \mathrm{A} \beta$ and $2.4 \mu \mathrm{M}$ peptides. Samples were incubated for $1 \mathrm{~h}$ at $37^{\circ} \mathrm{C}$ and then cross-linked by photoinduced method (PICUP) as previously described. ${ }^{34,47}$ Cross-linked samples were heated at $95^{\circ} \mathrm{C}$ for $5 \mathrm{~min}$ and separated on a 10 $20 \%$ Tris-Tricine gradient gel (Invitrogen, Carlsbad, CA) at $125 \mathrm{~V}$ for $100 \mathrm{~min}$, transferred onto a $0.2 \mu \mathrm{m}$ poly(vinylidene difluoride) (PVDF) membrane at $25 \mathrm{~V}$ for $90 \mathrm{~min}$, and detected by monoclonal mouse anti-A $\beta$ antibody 4G8 (BioLegend, San Diego, CA) as previously described. ${ }^{34}$ 


\section{Thioflavin T (ThT) Fluorescence Assay}

ThT (Sigma, St Louis, MO) stock solutions were prepared in PBS and filtered through 0.22 $\mu \mathrm{m}$ filter followed by concentration measurement using an extinction coefficient of 26620 $\mathrm{M}^{-1} \mathrm{~cm}^{-1}$ at $416 \mathrm{~nm}$ in ethanol. The stock solution was diluted to $10 \mu \mathrm{M}$ in PBS. A $\beta$ alone $(28 \mu \mathrm{M})$ and with peptides $(2.8,1.4$, and $0.28 \mu \mathrm{M})$ were prepared in PBSA and incubated at $37^{\circ} \mathrm{C}$. After 1 or 4,24 , and $48 \mathrm{~h}$ of incubation, $10 \mu \mathrm{L}$ of each sample was mixed with 130 $\mu \mathrm{L}$ of $10 \mu \mathrm{M}$ ThT and analyzed. ThT fluorescence emission was measured using a QuantaMaster spectrofluometer (PTI, Birmingham, NJ), with excitation at $440 \mathrm{~nm}$ and emission spectra recorded from 460 to $500 \mathrm{~nm}$. Three serial spectra were averaged for each sample and the background signal of ThT in PBS was subtracted from the averaged data. Fluorescence intensity at a wavelength of $480 \mathrm{~nm}$ was compared.

\section{Proteolytic Fragmentation Assay}

The proteolytic fragmentation assay of $\mathrm{A} \beta$ with peptides was performed as previously described, with some modifications. ${ }^{34}$ Briefly, $\mathrm{A} \beta$ alone $(20 \mu \mathrm{M})$ or with peptide $(1.4 \mu \mathrm{M})$ was incubated for $24 \mathrm{~h}$ at $37{ }^{\circ} \mathrm{C}$. Proteinase K (Promega) was added to the samples at a final concentration of $0.5 \mu \mathrm{g} / \mathrm{mL}$ and $1.5 \mu \mathrm{L}$ of each sample was dotted onto a $0.45 \mu \mathrm{m}$ nitrocellulose membrane after incubation for $0,5,10,15,20,30,40,50,60,90$, and 120 $\mathrm{min}$. Membranes were then detected by monoclonal mouse anti-A $\beta$ antibody $6 \mathrm{E} 10$ (Covance) as previously described. ${ }^{34}$

\section{Dynamic Light Scattering (DLS)}

$\mathrm{A} \beta$ alone $(28 \mu \mathrm{M})$ or with peptides (CG3 or CG8 at $1.4 \mu \mathrm{M})$ was filtered through a $0.45 \mu \mathrm{m}$ filter directly into a clean light scattering cuvette and placed into a bath of the indexmatching solvent decahydronaphthalene with temperature controlled to $37^{\circ} \mathrm{C}$. Light scattering data were collected at $90^{\circ}$ scattering angle using a Brookhaven BI-200SM system (Brookhaven Instruments Corp., Holtsville, NY) and an Innova 90C-5 argon laser (Coherent, Santa Clara, CA) operating at $488 \mathrm{~nm}$ and $150 \mathrm{~mW}$. The $z$-averaged hydrodynamic diameter was determined from the autocorrelation function using the method of cumulants. For each experiment, data collection time was 5 min to ensure adequate sampling.

\section{Nanopaticle Tracking Analysis (NTA)}

Nanosight LM10 (Nano-sight, Amesbury, U.K.) equipped with a $405 \mathrm{~nm}$ laser was used to collect NTA measurements. A $\beta$ alone $(28 \mu \mathrm{M})$ or with $1.4 \mu \mathrm{M}$ peptide was prepared in PBSA and injected into the sample chamber using a $1 \mathrm{~mL}$ syringe. Video capture was initiated immediately. For each measurement, one $60 \mathrm{~s}$ video was taken and analyzed using NTA 3.0 software. All measurements were collected at room temperature with camera level 13. All buffers were filtered through $0.02 \mu \mathrm{m}$ filters before use and checked for absence of scattering particles, by observation of a completely blank background. Particle number concentration was calculated based on a scattering volume that is a function of instrument settings. Particle data was exported with intensity and size for each tracked particles. 


\section{Transmission Electron Microscopy (TEM)}

$\mathrm{A} \beta$ alone $(28 \mu \mathrm{M})$ or with peptide (CG3 or CG8 at $1.4 \mu \mathrm{M})$ was prepared in PBSA and incubated for $24 \mathrm{~h}$ at $37{ }^{\circ} \mathrm{C}$. A drop of sample was placed on a pioloform-coated grid and stained with methylamine tungstate stain. Images were taken with a Philips CM120 scanning transmission electron microscope (FEI Corp., Eindhoven, The Netherlands).

\section{Supplementary Material}

Refer to Web version on PubMed Central for supplementary material.

\section{Acknowledgments}

Funding

This work was supported by National Institutes of Health Grant R01AG033493.

\section{ABBREVIATIONS}

$\begin{array}{ll}\text { A } \boldsymbol{\beta} & \boldsymbol{\beta} \text {-amyloid } \\ \text { AD } & \text { Alzheimer's disease } \\ \text { APP } & \text { amyloid precursor protein } \\ \text { ACN } & \text { acetonitrile } \\ \text { CD } & \text { circular dichroism } \\ \text { DLS } & \text { dynamic light scattering } \\ \text { HFIP } & \text { hexafluoroisopropanol } \\ \text { NTA } & \text { nanoparticle tracking analysis } \\ \text { PBS } & \text { phosphate-buffered saline } \\ \text { PICUP } & \text { photoinduced cross-linking of unmodified proteins } \\ \text { PyBOP } & \begin{array}{l}\text { benzotriazol-1-yl- } N \text {-oxy-tris(pyrrolidino)-phosphonium } \\ \text { hexafluorophosphate }\end{array} \\ \text { TEM } & \text { transmission electron microscopy } \\ \text { TTR } & \text { transthyretin }\end{array}$

\section{References}

1. Selkoe DJ. Resolving controversies on the path to Alzheimer's therapeutics. Nat Med. 2011; 17:1060-1065. [PubMed: 21900936]

2. Mattson MP. Pathways towards and away from Alzheimer's disease. Nature. 2004; 430:631-639. [PubMed: 15295589]

3. Mangialasche F, Solomon A, Winblad B, Mecocci P, Kivipelto M. Alzheimer's disease: clinical trials and drug development. Lancet Neurol. 2010; 9:702-716. [PubMed: 20610346] 
4. Salomone S, Caraci F, Leggio GM, Fedotova J, Drago F. New pharmacological strategies for treatment of Alzheimer's disease: focus on disease modifying drugs. Br J Clin Pharmacol. 2012; 73:504-517. [PubMed: 22035455]

5. Mohamed T, Shakeri A, Rao PPN. Amyloid cascade in Alzheimer's disease: Recent advances in medicinal chemistry. Eur J Med Chem. 2016; 113:258-272. [PubMed: 26945113]

6. Gouras GK, Olsson TT, Hansson O. $\beta$-Amyloid peptides and amyloid plaques in Alzheimer's disease. Neurotherapeutics. 2015; 12:3-11. [PubMed: 25371168]

7. Narayan P, Ehsani S, Lindquist S. Combating neurodegenerative disease with chemical probes and model systems. Nat Chem Biol. 2014; 10:911-920. [PubMed: 25325702]

8. Francioso A, Punzi P, Boffi A, Lori C, Martire S, Giordano C, D’Erme M, Mosca L. $\beta$-sheet interfering molecules acting against $\beta$-amyloid aggregation and fibrillogenesis. Bioorg Med Chem. 2015; 23:1671-1683. [PubMed: 25769517]

9. Porat Y, Abramowitz A, Gazit E. Inhibition of amyloid fibril formation by polyphenols: structural similarity and aromatic interactions as a common inhibition mechanism. Chem Biol Drug Des. 2006; 67:27-37. [PubMed: 16492146]

10. Ehrnhoefer DE, Bieschke J, Boeddrich A, Herbst M, Masino L, Lurz R, Engemann S, Pastore A, Wanker EE. EGCG redirects amyloidogenic polypeptides into unstructured, off-pathway oligomers. Nat Struct Mol Biol. 2008; 15:558-566. [PubMed: 18511942]

11. Ono K, Condron MM, Ho L, Wang J, Zhao W, Pasinetti GM, Teplow DB. Effects of grape seedderived polyphenols on amyloid $\beta$-protein self-assembly and cytotoxicity. J Biol Chem. 2008; 283:32176-32187. [PubMed: 18815129]

12. Soto-Ortega DD, Murphy BP, Gonzalez-Velasquez FJ, Wilson KA, Xie F, Wang Q, Moss MA. Inhibition of amyloid- $\beta$ aggregation by coumarin analogs can be manipulated by functionalization of the aromatic center. Bioorg Med Chem. 2011; 19:2596-2602. [PubMed: 21458277]

13. Wells JA, McClendon CL. Reaching for high-hanging fruit in drug discovery at protein-protein interfaces. Nature. 2007; 450:1001-1009. [PubMed: 18075579]

14. Nie Q, Du X, Geng M. Small molecule inhibitors of amyloid $\beta$ peptide aggregation as a potential therapeutic strategy for Alzheimer's disease. Acta Pharmacol Sin. 2011; 32:545-551. [PubMed: 21499284]

15. Panza F, Solfrizzi V, Imbimbo BP, Logroscino G. Amyloid-directed monoclonal antibodies for the treatment of Alzheimer's disease: the point of no return? Expert Opin Biol Ther. 2014; 14:14651476. [PubMed: 24981190]

16. Spencer B, Masliah E. Immunotherapy for Alzheimer's disease: past, present and future. Front Aging Neurosci. 2014; 6:114. [PubMed: 24959143]

17. Di L. Strategic approaches to optimizing peptide ADME properties. AAPS J. 2015; 17:134-143. [PubMed: 25366889]

18. Craik DJ, Fairlie DP, Liras S, Price D. The future of peptide-based drugs. Chem Biol Drug Des. 2013; 81:136-147. [PubMed: 23253135]

19. Doig AJ. Peptide inhibitors of $\beta$-amyloid aggregation. Curr Opin Drug Discovery Devel. 2007; 10:533-539.

20. Ghanta J, Shen CL, Kiessling LL, Murphy RM. A strategy for designing inhibitors of $\beta$-amyloid toxicity. J Biol Chem. 1996; 271:29525-29528. [PubMed: 8939877]

21. Lowe TL, Strzelec A, Kiessling LL, Murphy RM. Structure-function relationships for inhibitors of $\beta$-amyloid toxicity containing the recognition sequence KLVFF. Biochemistry. 2001; 40:78827889. [PubMed: 11425316]

22. Austen BM, Paleologou KE, Ali SAE, Qureshi MM, Allsop D, El-Agnaf OMA. Designing peptide inhibitors for oligomerization and toxicity of Alzheimer's $\beta$-amyloid peptide. Biochemistry. 2008; 47:1984-1992. [PubMed: 18189413]

23. Amijee H, Bate C, Williams A, Virdee J, Jeggo R, Spanswick D, Scopes DIC, Treherne JM, Mazzitelli S, Chawner R, Eyers CE, Doig AJ. The N-methylated peptide SEN304 powerfully inhibits $A \beta(1-42)$ toxicity by perturbing oligomer formation. Biochemistry. 2012; 51:8338-8352. [PubMed: 23025847] 
24. Turner JP, Lutz-Rechtin T, Moore KA, Rogers L, Bhave O, Moss MA, Servoss SL. Rationally designed peptoids modulate aggregation of amyloid-beta 40. ACS Chem Neurosci. 2014; 5:552558. [PubMed: 24689364]

25. Wiesehan K, Buder K, Linke RP, Patt S, Stoldt M, Unger E, Schmitt B, Bucci E, Willbold D. Selection of D-amino-acid peptides that bind to Alzheimer's disease amyloid peptide A $\beta 1-42$ by mirror image phage display. ChemBioChem. 2003; 4:748-753. [PubMed: 12898626]

26. Orner BP, Liu L, Murphy RM, Kiessling LL. Phage display affords peptides that modulate $\beta$ amyloid aggregation. J Am Chem Soc. 2006; 128:11882-11889. [PubMed: 16953628]

27. Acerra N, Kad NM, Griffith DA, Ott S, Crowther DC, Mason JM. Retro-inversal of intracellular selected $\beta$-amyloid-interacting peptides: implications for a novel Alzheimer's disease treatment. Biochemistry. 2014; 53:2101-2111. [PubMed: 24601543]

28. Chemerovski-Glikman M, Richman M, Rahimipour S. New perspectives in reducing amyloid aggregation and toxicity. Isr J Chem. 2015; 55:735-748.

29. Stein TD, Johnson JA. Lack of neuro-degeneration in transgenic mice overexpressing mutant amyloid precursor protein is associated with increased levels of transthyretin and the activation of cell survival pathways. J Neurosci. 2002; 22:7380-7388. [PubMed: 12196559]

30. Yang DT, Joshi G, Cho PY, Johnson JA, Murphy RM. Transthyretin as both a sensor and a scavenger of $\beta$-amyloid oligomers. Biochemistry. 2013; 52:2849-2861. [PubMed: 23570378]

31. Du J, Murphy RM. Characterization of the interaction of $\beta$-amyloid with transthyretin monomers and tetramers. Biochemistry. 2010; 49:8276-8289. [PubMed: 20795734]

32. Li X, Zhang X, Ladiwala ARA, Du D, Yadav JK, Tessier PM, Wright PE, Kelly JW, Buxbaum JN. Mechanisms of transthyretin inhibition of $\beta$-amyloid aggregation in vitro. J Neurosci. 2013; 33:19423-19433. [PubMed: 24336709]

33. Du J, Cho PY, Yang DT, Murphy RM. Identification of beta-amyloid-binding sites on transthyretin. Protein Eng, Des Sel. 2012; 25:337-345. [PubMed: 22670059]

34. Cho PY, Joshi G, Johnson JA, Murphy RM. Transthyretin-derived peptides as $\beta$-amyloid inhibitors. ACS Chem Neurosci. 2014; 5:542-551. [PubMed: 24689444]

35. Cho PY, Joshi G, Boersma MD, Johnson JA, Murphy RM. A cyclic peptide mimic of the $\beta$ amyloid binding domain on transthyretin. ACS Chem Neurosci. 2015; 6:778-789. [PubMed: 25713928]

36. Fernandez-Escamilla AM, Rousseau F, Schymkowitz J, Serrano L. Prediction of sequencedependent and mutational effects on the aggregation of peptides and proteins. Nat Biotechnol. 2004; 22:1302-1306. [PubMed: 15361882]

37. Syud FA, Stanger HE, Gellman SH. Interstrand side chain-side chain interactions in a designed $\beta$ hairpin: significance of both lateral and diagonal pairings. J Am Chem Soc. 2001; 123:8667-8677. [PubMed: 11535071]

38. Lu X, Murphy RM. Asparagine Repeat Peptides: Aggregation Kinetics and Comparison with Glutamine Repeats. Biochemistry. 2015; 54:4784-4794. [PubMed: 26204228]

39. Walters RH, Murphy RM. Aggregation kinetics of interrupted polyglutamine peptides. J Mol Biol. 2011; 412:505-519. [PubMed: 21821045]

40. Biancalana M, Koide S. Molecular mechanism of Thioflavin-T binding to amyloid fibrils. Biochim Biophys Acta, Proteins Proteomics. 2010; 1804:1405-1412.

41. Nordstedt C, Näslund J, Tjernberg LO, Karlström AR, Thyberg J, Terenius L. The Alzheimer A $\beta$ peptide develops protease resistance in association with its polymerization into fibrils. J Biol Chem. 1994; 269:30773-30776. [PubMed: 7983005]

42. Yang DT, Lu X, Fan Y, Murphy RM. Evaluation of nanoparticle tracking for characterization of fibrillar protein aggregates. AIChE J. 2014; 60:1236-1244. [PubMed: 25843955]

43. Fowler SB, Poon S, Muff R, Chiti F, Dobson CM, Zurdo J. Rational design of aggregation-resistant bioactive peptides: reengineering human calcitonin. Proc Natl Acad Sci U S A. 2005; 102:1010510110. [PubMed: 16006528]

44. Tsutsumi M, Otaki JM. Parallel and antiparallel $\beta$-strands differ in amino acid composition and availability of short constituent sequences. J Chem Inf Model. 2011; 51:1457-1464. [PubMed: 21520893] 
45. Saido T, Leissring MA. Proteolytic degradation of amyloid $\beta$-protein. Cold Spring Harbor Perspect Med. 2012; 2:a006379.

46. Anthis NJ, Clore GM. Sequence-specific determination of protein and peptide concentrations by absorbance at $205 \mathrm{~nm}$. Protein Sci. 2013; 22:851-858. [PubMed: 23526461]

47. Bitan G, Lomakin A, Teplow DB. Amyloid $\beta$-protein oligomerization: prenucleation interactions revealed by photo-induced cross-linking of unmodified proteins. J Biol Chem. 2001; 276:3517635184. [PubMed: 11441003] 


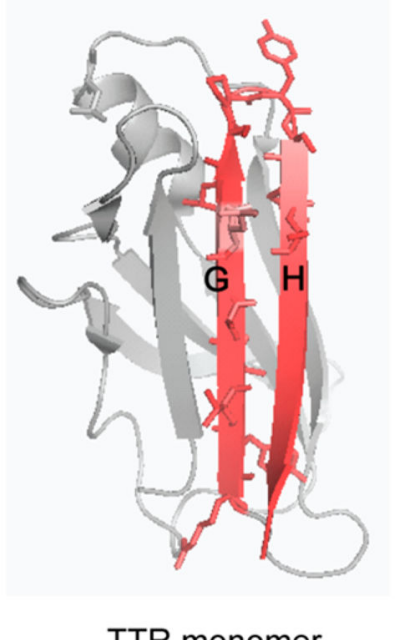

TTR monomer

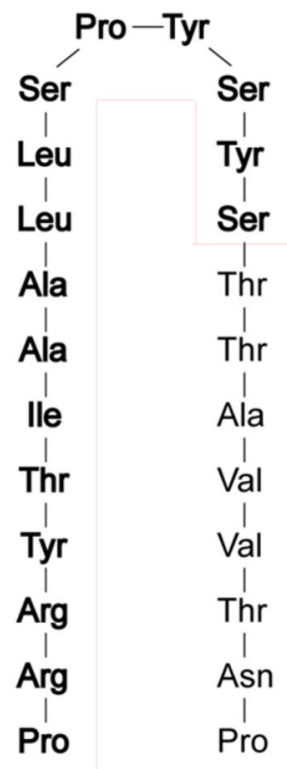

Pro

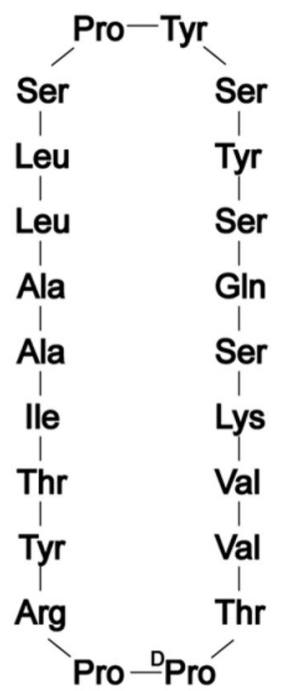

CG3

\section{G16 (PRRYTIAALLSPYSWS)}

Figure 1.

Comparison of TTR and CG3. (Left) Ribbon structure of transthyretin (PDB entry 1DVQ) monomer, showing strands $\mathrm{G}$ and $\mathrm{H}$ in red. Side chains from residue 102 to 117 are shown explicitly. L110, a critical binding residue, is shown in light red. (Center) Sequence of strands $\mathrm{G}$ and $\mathrm{H}$, with the bold region corresponding to the sequence of G16. Tyr was replaced by Trp for fluorescence study. (Right) Sequence of cyclic peptide CG3, mimicking the structure of strand $\mathrm{G} / \mathrm{loop} /$ strand $\mathrm{H}$ using Pro-Pro $\beta$-turn template. 


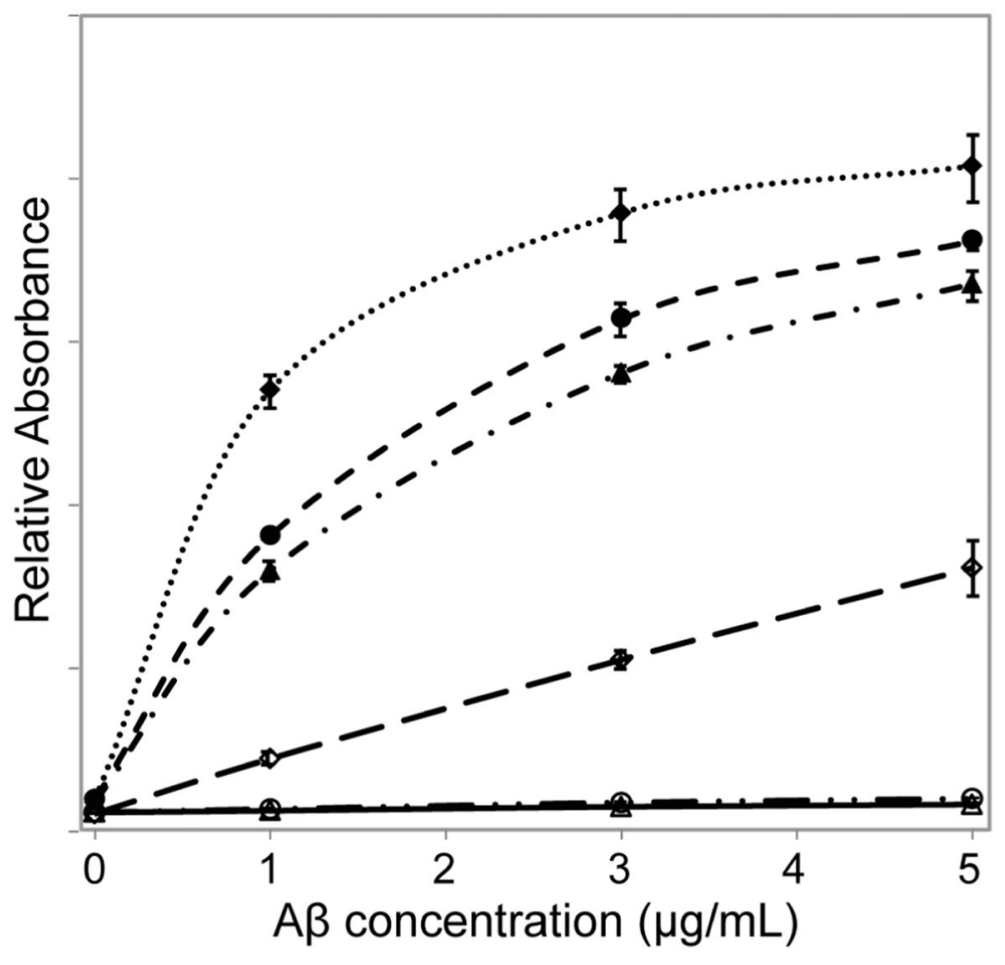

Figure 2.

$\mathrm{A} \beta$ binding to immobilized CG3. Relative binding was measured by ELISA. With CG3b coated, A $\beta$ binding was measured with no FBS $(\boldsymbol{\gamma}$, dot line); $10 \%$ FBS $(\boldsymbol{O}$, dash line $)$; and $30 \%$ FBS ( $\boldsymbol{\Delta}$, dash-dot line). Without CG3b coated, A $\beta$ binding was measured with no FBS $(\diamond$, long dash line); $10 \%$ FBS $(\bigcirc$, long dash-dot-dot line); and $30 \%$ FBS $(\Delta$, solid line). 

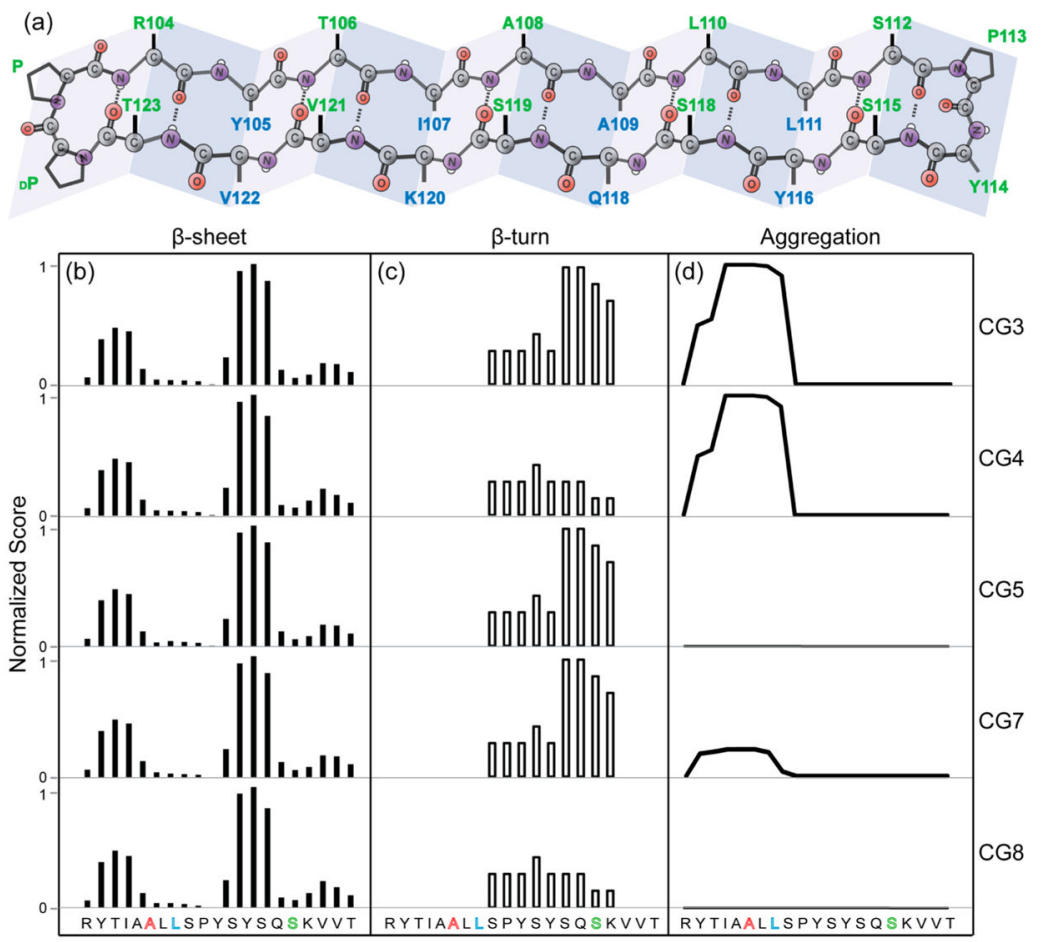

Figure 3.

Closer look at cyclic peptide structure and the TANGO mutation analysis. (a) CG3 structure of cyclized antiparallel $\beta$ strands. Amino acids on the putative $\mathrm{A} \beta$ binding site are in green and those on the other side are in blue. TANGO algorithm prediction of (b) $\beta$-sheet, (c) $\beta$ turn, and (d) aggregation scores was analyzed based on peptide sequences from R104 to T123 for CG3 (sequence shown at the bottom), CG4 (S119T), CG5 (A109K), CG7(L111S), and CG8 (S119T/A109K/L111S). 


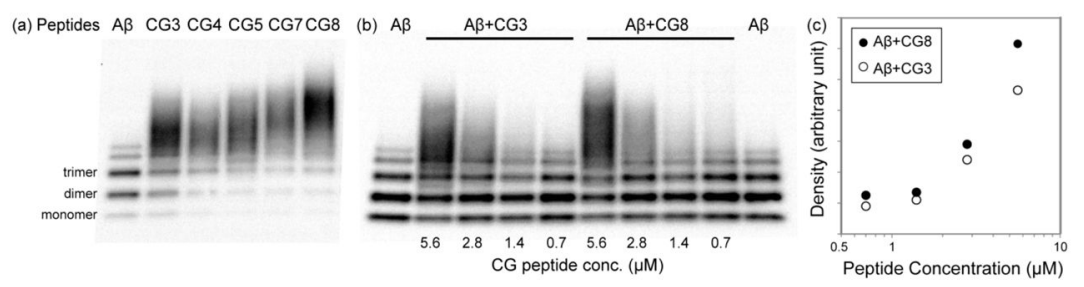

Figure 4.

Interaction of cyclic peptides with $\mathrm{A} \beta$ by photoinduced cross-linking (PICUP). (a) $\mathrm{A} \beta$ was incubated without or with peptides CG3, CG4, CG5, CG7, and CG8 where A $\beta$ concentration is in 10-fold excess. Samples were cross-linked, separated on gels, and detected via Western blotting with 4G8. (b) Concentration dependence of interaction between A $\beta$ and CG3/CG8. (c) Densities of high-molecular-weight bands quantified by ImageJ. Densities of all material greater than tetramer were measured. 

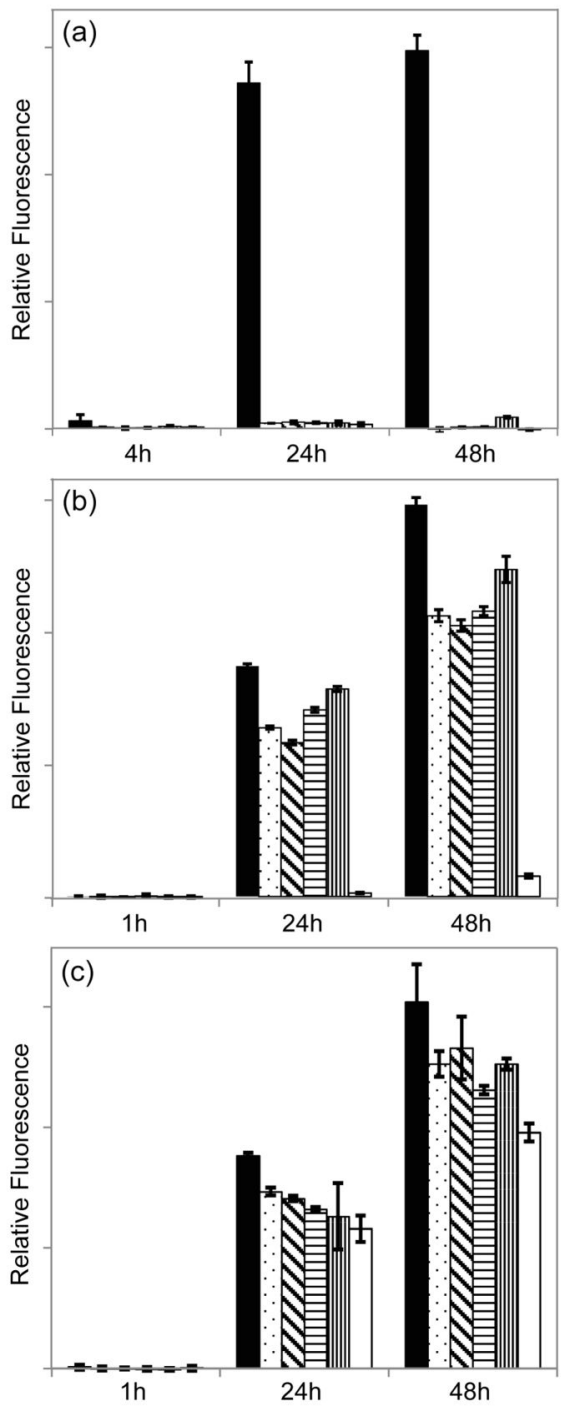

Figure 5.

Effect of cyclic peptides on A $\beta$ fibril formation measured by ThT fluorescence. Samples of $28 \mu \mathrm{M} \mathrm{A} \beta$ samples alone or with (a) $2.8 \mu \mathrm{M}$, (b) $1.4 \mu \mathrm{M}$, and (c) $0.28 \mu \mathrm{M}$ of peptides were incubated for 1 or 4,24 , and $48 \mathrm{~h}$. The ThT fluorescence intensity was compared for $\mathrm{A} \beta$ alone (solid), or with CG3 (dot), CG4 (diagonal), CG5 (horizontal), CG7 (vertical), or CG8 (open). Three replicates were averaged for each sample. 

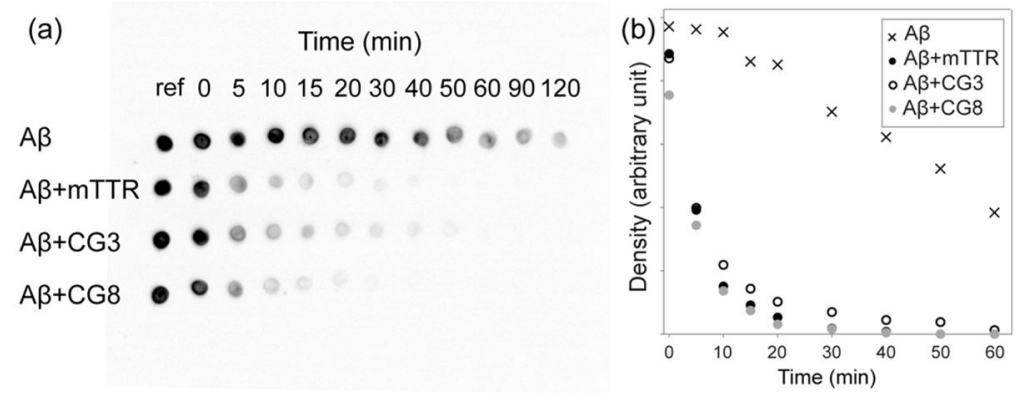

Figure 6.

Effect of CG3 and CG8 on A $\beta$ fibril formation investigated by proteolytic fragmentation assay. $\mathrm{A} \beta$ samples were incubated alone or with mTTR, CG3, or CG8 for $24 \mathrm{~h}$. (a) Relative rate of proteolytic fragmentation of $\mathrm{A} \beta$ was measured by subsequent addition of proteinase $\mathrm{K}$ followed by dotting onto nitrocellulose membrane at different time points. Unfragmented $\mathrm{A} \beta$ species were detected by $6 \mathrm{E} 10$ antibody. (b) Density of dots was quantified using ImageJ. The data were fit to a single exponential decay and half-times were determined to be 38 min for $\mathrm{A} \beta, 18$ min for $\mathrm{A} \beta+\mathrm{CG} 3$, and $10 \mathrm{~min}$ for $\mathrm{A} \beta+\mathrm{CG} 8$ and $\mathrm{A} \beta+\mathrm{mTTR}$. 

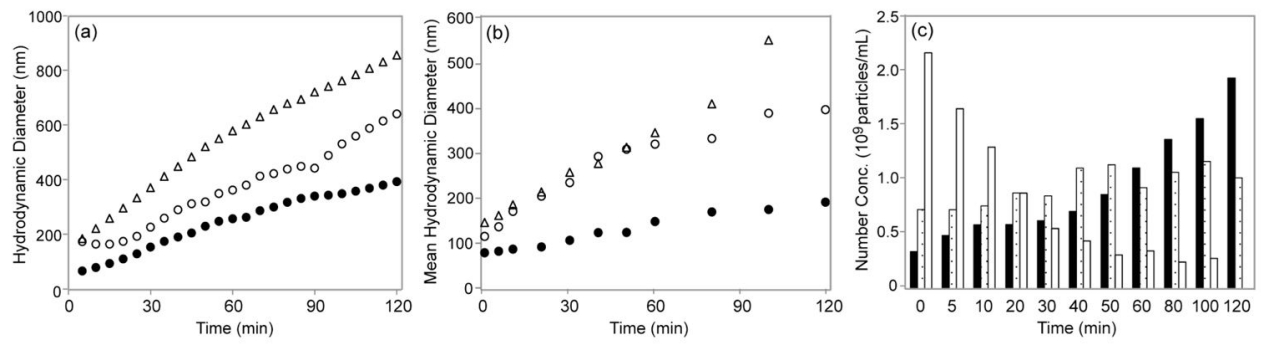

Figure 7.

Effect of CG3 and CG8 on A $\beta$ aggregates growth kinetics measured by DLS and NTA. Samples were prepared at $28 \mu \mathrm{M} \mathrm{A} \beta$ without or with $1.4 \mu \mathrm{M} \mathrm{CG} 3$ or CG8. (a) Mean hydrodynamic diameter measured by DLS. A $\beta(\bigcirc)$, A $\beta+\mathrm{CG} 3(\bigcirc)$, or A $\beta+\mathrm{CG} 8(\Delta)$. (b) Mean hydrodynamic diameter measured by NTA. (c) Particle number concentration measured by NTA as a function of time for $\mathrm{A} \beta$ (solid), $\mathrm{A} \beta+\mathrm{CG} 3$ (dot), and $\mathrm{A} \beta+\mathrm{CG} 8$ (open). 

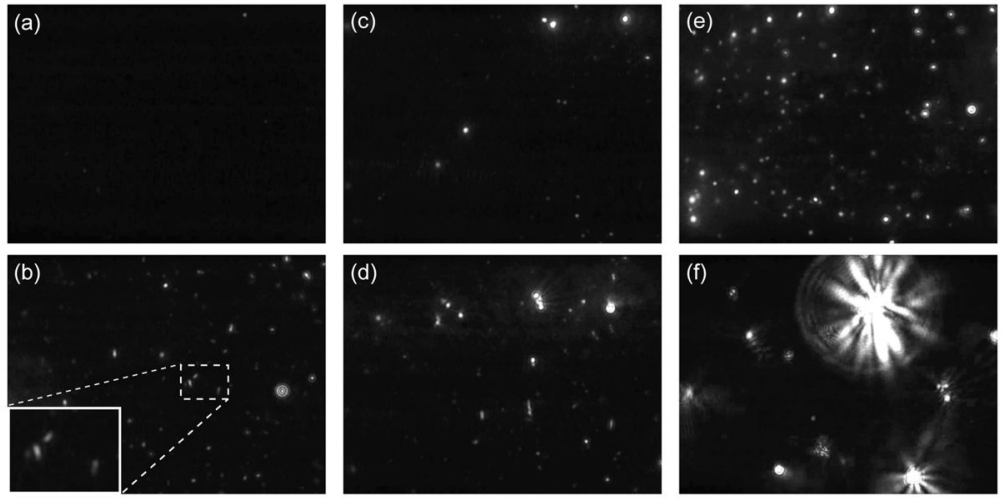

Figure 8.

Still images taken from NTA videos collected for (a) $\mathrm{A} \beta$ at 0 min, (b) $\mathrm{A} \beta$ at 120 min (inset: prefibrillar aggregates), (c) $\mathrm{A} \beta+\mathrm{CG} 3$ at $0 \mathrm{~min},(\mathrm{~d}) \mathrm{A} \beta+\mathrm{CG} 3$ at $120 \mathrm{~min},(\mathrm{e}) \mathrm{A} \beta+\mathrm{CG} 8$ at 0 min, and (f) $\mathrm{A} \beta+\mathrm{CG} 8$ at $120 \mathrm{~min}$. 

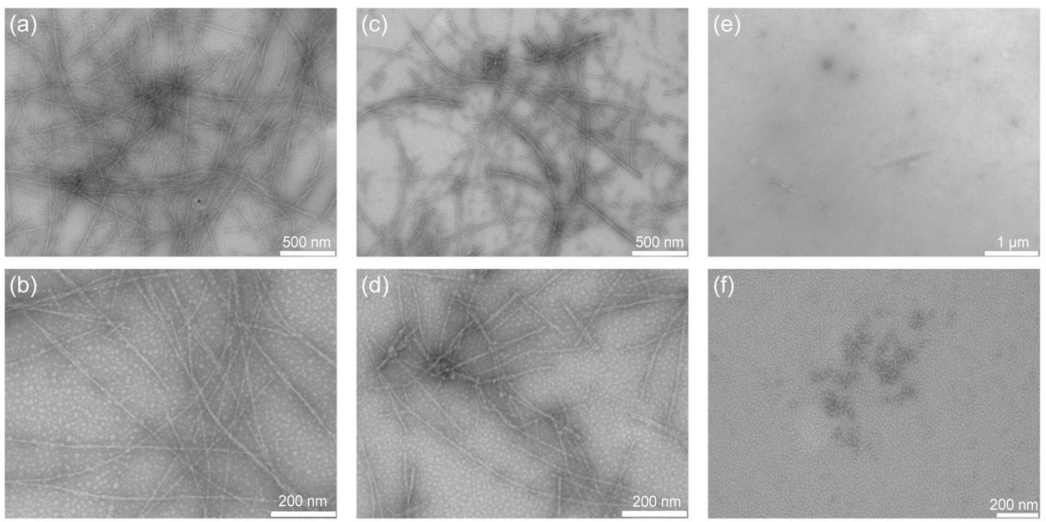

Figure 9.

TEM images taken after $24 \mathrm{~h}$ incubation at $37^{\circ} \mathrm{C}$. (a,b) $28 \mu \mathrm{M} \mathrm{A} \beta$, (c,d) $28 \mu \mathrm{M} \mathrm{A} \beta+1.4$ $\mu \mathrm{M} \mathrm{CG} 3$, and (e,f) $28 \mu \mathrm{M} \mathrm{A} \beta+1.4 \mu \mathrm{M}$ CG8. 


\section{Table 1}

Peptide Properties

\begin{tabular}{ccccc}
\hline peptide & molecular weight (Da) $)^{\boldsymbol{a}}$ & $\begin{array}{c}\text { ellipticity at } \mathbf{1 9 7} \mathbf{~ n m}\left(\mathbf{1 0}^{-\mathbf{4}} \mathbf{d e g ~ \mathbf { ~ m } ^ { 2 } /}\right. \\
\mathbf{d m o l})^{\boldsymbol{b}}\end{array}$ & $\begin{array}{c}\text { RP-HPLC elution }(\% \\
\text { acetonitrile) }^{\boldsymbol{c}}\end{array}$ & stability (cyclic:linear) $^{\boldsymbol{d}}$ \\
\hline CG3 & 2423 & -0.55 & 44.5 & $17 \%: 83 \%$ \\
CG4 & 2347 & -0.45 & 44.5 & $20 \%: 80 \%$ \\
CG5 & 2480 & -0.50 & 43.3 & $60 \%: 40 \%$ \\
CG7 & 2397 & -0.65 & 41.7 & $40 \%: 60 \%$ \\
CG8 & 2468 & -0.55 & 41.7 & $70 \%: 30 \%$
\end{tabular}

${ }^{a}$ Measured molecular weight by mass spectrometry.

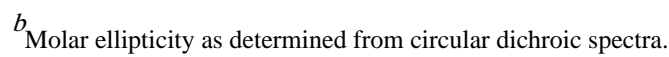

${ }^{c}$ Wt $\%$ acetonitrile in eluting buffer, during RP-HPLC purification.

${ }^{d}$ Determined as the ratio of peaks in mass spectra after $1 \mathrm{~h}$ incubation with proteinase $\mathrm{K}$. Additional fragments were observed in the spectra but are not considered. 